\title{
Membrane Protein as Novel Targets for Vaccine Production in Haemophilus influenzae and Neisseria meningitidis
}

Julia Nogueira Varela, Mário Sérvulo Izidoro Jr, Luciana Maria de Hollanda and Marcelo Lancellotti*

Biotechnology Laboratory, Department of Biochemistry, Institute of Biology, State University of Campinas -UNICAMP, Brazil

\begin{abstract}
Haemophilus influenzae and Neisseria meningitis are gram negative, commensal bacteria naturally present in the nasopharynx. They are also naturally competent and suffer genetic mutations. $H$. influenzae causes diseases such as otitis media and pneumonia. While N. meningitis causes pneumonia, meningitis and sepsis. With the introduction of a vaccination program, a decrease in cases and deaths caused by these pathogens were observed over the following years. Especially, in countries where these vaccines were included in the vaccination schedule and in endemic regions, such as the meningitis belt in Africa. However, there are serotypes, biotypes and strains that these vaccines do not cover. Thus, these strains, biotypes and serotypes are emerging as pathogenic ones. Concerning the health authorities because the diagnosis of these diseases is most of the times unreliable and treatment needs to be immediate, due to the rapid evolution of the disease. For these emerging bacteria novel immunogenic targets are being researched as a way of trying to find and design new vaccines. These vaccines can be aimed in membrane proteins. Using these proteins as immunogenic targets with the help of adjuvants, to boost the immune system. The burden of a death or sequel to children and even adults that undergo meningitis infection and treatment is high. Therefore prevention is the best alternative. The aim of this review is to present this novel targets and their pros and cons. As a way of enlighten researches to view this new group of molecules and ligands as a possible target.
\end{abstract}

Keywords: Haemophilus influenza; Membrane proteins; Neisseria meningitides; Vaccine; Membrane vaccines

\section{Introduction}

Haemophilus influenzae and Neisseiria meningitidis are gram negative commensal bacteria to the human upper respiratory tract [1].

Haemophilus influenza is a pleomorphic bacillus that has been associated with localized and invasive infections, such as bronchitis, otitis, pneumonia, meningitis, septicemia, and epiglottitis [2,3].

$H$. influenzae is also responsible for most of the meningitis in children between 2 and 5 years old [4,5]. H. influenzae type b (Hib) is the most invasive type of six capsular serotypes (a-f) and is recognized as a major cause of meningitis [6].

The NTHi is typically associated with moderate disease from the upper respiratory tract in children and pneumonia in adults with cystic fibrosis or chronicle obstructive disease [7]. The NTHi is a predominant bacterial agent of the prevalent pediatric disease otitis media (OM), and is also responsible for multiple diseases of the upper and lower respiratory tracts of both children and adults, although a commensal of the upper respiratory tracts of healthy persons, is an important cause of acute, recurrent, and persistent infections of the human respiratory tract [4].

In the United States, the overall annual incidence of Hib meningitis in children aged 0 to 4 years was about 50 to 60 per 100,000 (ranging from 19 to 69 per 100,000) prior to vaccine availability; the average was 54 per 100,000. This incidence was greater than twice the weighted average for pre vaccination Europe, 23 per 100,000 [3].

After the introduction of the Hib conjugate vaccine in the Netherlands in 1993, the incidence of Hib infections strongly decreased to very low levels in all age groups. However, NTHi infections have been reported to increase over time after Hib vaccine introduction [8]. There is no vaccine available for the NTHi and there is an emergence of this pathogen [9]. There are still related cases in the literature of Hib invasive disease post vaccination period $[10,11]$.
$N$. meningitidis is a gram negative coccus that is a major cause of meningitis and septicemia globally, predominantly affecting children and adolescents. Meningococcal meningitis and sepsis are devastating diseases that kills children and young adults within hours despite the availability of effective antibiotics. Mortality and permanent disability rates are high, even under optimal health care conditions has also been associated with these infections [12].

Meningitis caused by bacterial infections is more likely to come with complications such as high mortality and morbidity levels. Among survivors, up to $20 \%$ have significant sequelae, including neurologic disability, amputation, and hearing loss [13]. The infections by meningococcal in the United States occur sporadically or in small clusters, and the most common Neisseira meningitidis serogroups involved are B, C, and Y. In some parts of the developing world, most notably across the center of Africa, serogroups A and, more recently, W135 cause severe epidemic disease [14].

The diagnosis of meningococcal disease presents challenges to the clinician because symptoms are similar to those of less serious illnesses, the symptoms have a sudden onset, and the disease may rapidly progress to permanent disability or death $[15,16]$. Neisseria meningitidis remains a major and insidious cause of death, even in industrialized countries

*Corresponding author: Dr Marcelo Lancellotti, Department of Biochemistry, Institute of Biology CP6109, State University of Campinas - UNICAMP, 13083-970 Campinas, SP, Brazil, Tel: +55 19352161 50; Fax: +55 193521 6129; E-mail: mlancell@unicamp.br

Received August 28, 2012; Accepted October 10, 2012; Published October 14 2012

Citation: Varela JN, Izidoro Jr MS, de Hollanda LM, Lancellotti M (2012) Membrane Protein as Novel Targets for Vaccine Production in Haemophilus influenzae and Neisseria meningitidis. J Vaccines Vaccin 3:152. doi:10.4172/2157-7560.1000152

Copyright: @ 2012 Varela JN, et al. This is an open-access article distributed unde the terms of the Creative Commons Attribution License, which permits unrestricted use, distribution, and reproduction in any medium, provided the original author and source are credited. 
tetravalent meningococcal glycoconjugate vaccine Men-ACWY was well tolerated and immunogenic for serogroups A, C, W-135, and Y when given to healthy infants at either 2,3 , and 4 months or 2,4 , and 6 months of age [13]. Immunological evaluation of the N. meningitidis 4 vaccines serogroups in children demonstrated it is less immunogenic in children than in adolescents [13]. In table 1 we can visualize the existing vaccines available for $N$. meningitidis today.

As for $H$. influenzae encapsulated strains, few vaccines in history have induced such a dramatic decline in incidence over such a short period as have the Hib conjugates vaccines [3]. Prior to the introduction of Haemophilus b Conjugate Vaccines, Haemophilus influenzae type $\mathrm{b}$ (Hib) was the most frequent cause of bacterial meningitis and a leading cause of serious, systemic bacterial disease in young children worldwide [31]. In addition to protecting against invasive infection, $\mathrm{Hib}$ conjugate vaccine prevents asymptomatic oropharyngeal (OP) Hib colonization or carriage. The lower prevalence of Hib carriage in the population decreases the risk of infection even among unvaccinated children through reduced transmission [32].

The World Health Organization recommends that Hib vaccine now be included in routine infant immunization programmes for all children, as appropriate to national capacities and priorities [24]. Several Hib conjugate vaccines are available from different manufacturers. All manufacturers use the capsular polysaccharide material of the bacteria and link it to tetanus toxoid, diphtheria toxoid, a diphtheria toxoid-like protein, or a mix of proteins from another bacterium. Each of these has been proven effective in the prevention of Hib disease [24].

There are three Hib conjugate vaccines licensed for use in infants $<15$ months old in the United States. The Hib conjugate vaccine polyribosylribitol phosphate Neisseria meningitidis outer membrane protein vaccine (PRP-OMP) (PedVaxHIB; Merck, Rahway, NJ) provides the earliest antibody levels thought to be protective against invasive disease. However, PRP-OMP vaccination does not achieve as high a peak antibody concentration after a full course as is seen after vaccination with either the Hib oligosaccharide CRM197 (HbOC) or polyribosylribitol phosphate tetanus toxoid (PRP-T) vaccines [11]. We can see the available commercial vaccines presented in the USA in table 2 .

\section{The Membrane Proteins in H. influenzae}

A reasonable number of outer-membrane proteins in $H$. influenzae have been studied. Most of them came from isolates of $H$. influenzae type $\mathrm{b}$ that are usually examined by sodium dodecyl sulfate-polyacrylamide gel electrophoresis (SDS-PAGE) [35].

When analyzed both encapsulated and non encapsulated $H$. influenzae strains showed protein components to contain up to 36 proteins of which 6 represent the major protein content. These major proteins have molecular weights between 50,000 and 15,000 and are labelled P1 to P6 in order of decreasing molecular mass. The proteins of the NTHi strains show greater variability in their migration patterns than do those of the $H$. influenzae type $\mathrm{b}$ strains. However, the general terminology of P1 to P6 has been transposed to the NTHi strains [36].

The P1 is a heatmodifiable surface exposed protein found in $H$. influenzae type b and NTHi. Significant variability in the primary protein sequence in the variable region of $\mathrm{P} 1$ and its ability to be modified by heat allowed it to be used as a form of subtyping for $H$. influenzae type b strains [35].

The P2 protein of different Hib strains was also studied, and it was indicated that some degree of antigenic heterogeneity existed among this protein from strain to strain. Being the P2 is a surface-exposed protein that functions as a porin in Hib and also represents the most abundant protein in the outer membrane of this pathogen $[37,38]$.

According to a study by Tokudu et al. it is suggested that P2 molecules and surface antigens other than $\mathrm{P} 2$ are involved in the development of pulmonary defense against $\mathrm{NTHi}$, and it also suggested that a host previously infected by a NTHi continues to be susceptible to infections by other strains of NTHi with different P2 epitopes [20]. The $\mathrm{P} 4$, protein, is a 28 to $30 \mathrm{kDa}$ lipoprotein that is thought to be present in all encapsulated and nonencapsulated $H$. influenzae strains [36]. Figure 1 shows these important outer membrane proteins.

\section{The Membrane Proteins in N. meningitidis}

There are several distinct adhesins in N. meningitidis between those the NadA, YadA and UspAs have proven to be the more immunogenic ones. NadA is a protein of 362 amino acids with a possible leader peptide of 23 amino acids [39]. The NadA - Neisseria Adhesin A - is a surface exposed trimeric protein inducing bactericidal response in vivo. The nadA gene is present in approximately $50 \%$ of pathogenic meningococcal isolates and cluster into three well-conserved genetic and antigenic cross-reactive variants (NadA1-3) [40]. The PorA that composes the new vaccine against Neisseria meningitidis. Penicillinbinding proteins (PBPs) are conserved proteins that play a major role in peptidoglycan biosynthesis. PBP2 shows a highly conserved N-terminal part as well as highly conserved catalytic motifs in its C-terminal part [18]. The results obtained in this work using convalescent sera demonstrate the immunogenicity of meningococcal PBP2.

PBP2 is associated with the membrane fraction in N. meningitidis and it is also accessible in these fractions for binding of radiolabelled penicillin G.16. Moreover, whole cell ELISA using anti- PBP2 IgG clearly showed a dose-dependent binding of anti-PBP2 antibodies to intact bacteria. These data cast light on the immunogenic/antigenic

\begin{tabular}{|c|c|c|c|}
\hline Existing Vaccines & Dosage & Advantages & Drawbacks \\
\hline $\begin{array}{l}\text { Hib - Haemophilus b } \\
\text { Conjugate Vaccine } \\
\text { (Tetanus Toxoid Conjugate) } \\
\text { ActHIB } \otimes \text { - Sanofi-Pasteur }\end{array}$ & $\begin{array}{l}1 \text { dose of } 0.5 \mathrm{ml} \text { contains } 10 \mu \mathrm{g} \\
\text { purified polysaccharide, } 3 \text { doses } \\
\text { with } 6 \text { to } 8 \text { weeks of interval. } \\
\text { (Intramuscular) }\end{array}$ & $\begin{array}{l}\text { Can be used in children as young } \\
\text { as } 2 \text { months old - achieve high peak } \\
\text { antibody concentration }\end{array}$ & $\begin{array}{l}\text { Only protects against type } b \text {, and does not offer } \\
\text { coverage to emerging non-capsulated groups } \\
{[11,33]}\end{array}$ \\
\hline $\begin{array}{l}\text { Haemophilus b conjugate Vaccine } \\
\text { (Diphtheria CRM197 Protein Conjugate) } \\
\text { HibTITER®- Wyeth Lederle }\end{array}$ & $\begin{array}{l}1 \text { dose contains } 10 \mu \mathrm{g} \text { of purified } \\
\text { Haemophilus b saccharide and } 25 \\
\mu \mathrm{g} \text { of CRM197 protein. } 3 \text { doses with } \\
2 \text { months interval. (Intramuscular) }\end{array}$ & $\begin{array}{l}\text { Achieve high peak antibody } \\
\text { concentration, offer long term } \\
\text { protection. }\end{array}$ & $\begin{array}{l}\text { Only protects against type b, and does not offer } \\
\text { coverage to emerging non-capsulated groups [11]. }\end{array}$ \\
\hline $\begin{array}{l}\text { Liquid PedvaxHIB® } \\
\text { [Haemophilus b Conjugate Vaccine } \\
\text { (Meningococcal Protein Conjugate)]- } \\
\text { Merk }\end{array}$ & $\begin{array}{l}1 \text { dose contains } 7.5 \mu \mathrm{g} \text { of Haemophilus b } \\
\text { PRP (polysaccharide capsule), } 125 \mu \text { of } \\
N \text {. meningitidis OMPC and } 225 \mu \mathrm{g} \text { of } \\
\text { aluminum (Intramuscular) }\end{array}$ & $\begin{array}{l}\text { Provides the earliest antibody levels } \\
\text { thought to be protective against } \\
\text { invasive } \\
\text { disease. }\end{array}$ & $\begin{array}{l}\text { Only protects against type } b \text {, and does not } \\
\text { offer coverage to emerging non-capsulated } \\
\text { groups. Does not achieve high peak antibody } \\
\text { concentration as the other two vaccines }[11,34] \text {. }\end{array}$ \\
\hline
\end{tabular}

Table 2: Commercial available vaccines for $H$. influenzae available in the USA. 


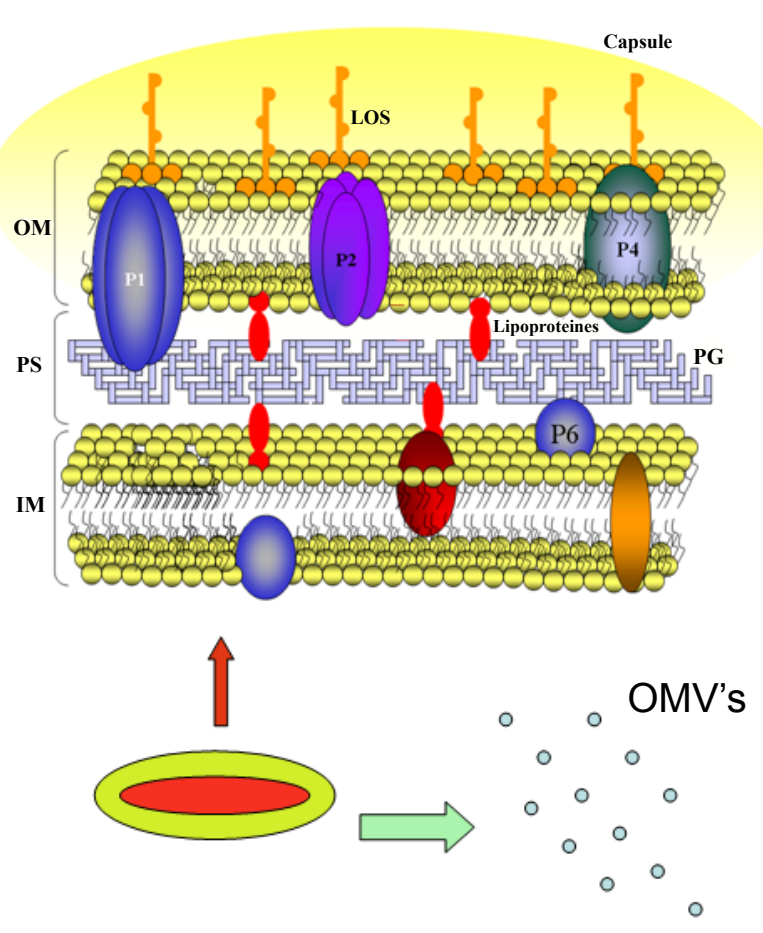

Haemophilus influenzae
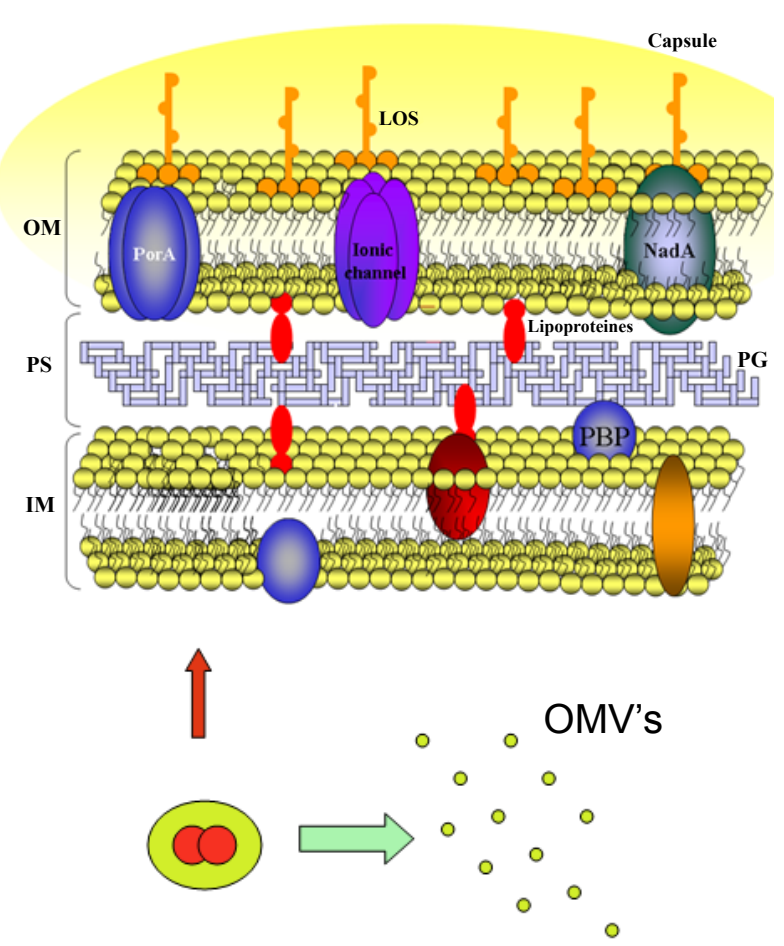

Neisseria meningitidis

Figure 1: Schematic representation of membrane proteins and outer membrane vesicules of Haemophilus influenzae and Neisseria Meningitidis as novel vaccine targets. In both schematic representation the (OM) is the outer membrane, (PS) periplasmatic space and (IM) inner membrane.

properties of meningococcal PBP2 [25]. Figure 1 shows these membrane proteins.

\section{The Nouvel Vaccine Targets in Haemophilus influenzae}

Interest in the H.influenzae Outer Membrane Proteins has centered mainly on their antigenic qualities as potential vaccine candidates [36]. However, one important criterion that must be met so that an Hib outer membrane protein can be a successful vaccine is that the protein must possess surface-exposed and antibody accessible antigenic determinants that are common to most if not all strains of this pathogen. At least three Hib outer membrane proteins appear to satisfy this requirement. Data concerning the P6 protein indicate that this protein has at least one surface epitope that is common to all strains of this pathogen [41].

P2 and P6 have generated the most interest to date as potential vaccine candidates against nontypeable $H$. influenza [35]. P4 has one surface-exposed epitope was conserved across the 28 clinical isolates tested, while $\mathrm{P} 5$ is a heat-modifiable $27 \mathrm{kDa}$ OMP. This protein is the lower-molecular-weight OMP, both of them, after in vitro and vivo trials did not demonstrated effective antigenicity [36].

Monoclonal antibodies raised against 8 epitopes of $\mathrm{P} 1$ protein from $H$. influenzae type $\mathrm{b}$ demonstrated significant areas of conservation among typeable and nontypeable strains. The potential for P1 as a vaccine candidate against NTHi shows mixed results at this stage. Antisera raised in rabbits to any of the eight conserved epitopes showed no bactericidal activity against NTHi [42].

The P2 major outer membrane protein of Hib and NTHi represents one of the four protein antigens the most dominant band on SDSPAGE OMP preparations. Purified P2 has been shown to induce the synthesis of antibodies protective against experimental Hib disease. Analysis of sequences of $\mathrm{P} 2$ from different strains reveals the presence of both heterogeneous and conserved surface-exposed loops of the P2 molecule among strains $[43,44]$.

Bactericidal antibodies to P2 are present in normal human sera. Immunization with a P2-LOS complex in mice and purified P2 preparation in a rat model showed enhanced pulmonary clearance of a homologous strain of NTHi. Immunization with P2, however, did not enhance clearance as much as did immunization with P1 or P6 $[36,44]$.

The study by Neary et al shows that antibody specificity to P2 loop 6 is high. With rabbits immunized as follows: $50 \mu \mathrm{g}$ of loop 6 Multiple Antigenic Pepetide (MAP) in complete Freund's adjuvant was administered subcutaneously on day 0 , and $50 \mu \mathrm{g}$ of loop 6 MAP in incomplete Freund's adjuvant was administered subcutaneously on days 14 and 28. Blood was obtained on day 35. And the antibodies were recovered by affinity chromatography demonstrating that $\mathrm{P} 2$ is a possible candidate for vaccination produce [22].

P6 (PAL) is a $16 \mathrm{kDa}$ lipoprotein found in all $H$. influenzae type $\mathrm{b}$ and NTHi strains. It elicits bactericidal antibody [45]. Since this protein is highly conserved among encapsulated and non encapsulated H. influenzae strains [44], surface exposed, and immunogenic, its' as a potential vaccine candidate is highly explored. Experiments demonstrating enhanced pulmonary clearance of homologous and heterologous strains of NTHi, after gut immunization with the purified protein are encouraging. Mice and rabbits have been shown to produce 


\begin{tabular}{|c|c|c|c|}
\hline Target & Advantages & Drawbacks & Preliminary data \\
\hline Outer Membrane Protein - P1 & $\begin{array}{l}\text { Significant areas of conservation among } \\
\text { typeable and nontypeable strains }\end{array}$ & $\begin{array}{l}\text { Only } 1 \text { epitope in common } \\
\text { between } 28 \text { strains tested }\end{array}$ & $\begin{array}{l}\text { Rabbit antisera presented bactericidal activity against } \\
\text { NTHi [42]. }\end{array}$ \\
\hline Outer Membrane Protein - P2 & $\begin{array}{l}\text { reveals the presence of both heterogeneous } \\
\text { and conserved surface-exposed loops of the } \\
\text { P2 molecule among strains } \\
\text { Bactericidal antibodies to P2 are present in } \\
\text { normal human sera }\end{array}$ & $\begin{array}{l}\text { Immunization with } \mathrm{P} 2 \text {, did not } \\
\text { enhance clearance as much as } \\
\text { did immunization with } \mathrm{P} 1 \text { or } \mathrm{P} 6 \text {. }\end{array}$ & $\begin{array}{l}\text { Induce the synthesis of antibodies protective against } \\
\text { experimental Hib disease. Immunization with a P2-LOS } \\
\text { complex in mice and purified P2 preparation in a rat model } \\
\text { showed enhanced pulmonary clearance of a homologous } \\
\text { strain of NTHi }[22,43,44] \text {. }\end{array}$ \\
\hline Outer Membrane Protein - P4 & $\begin{array}{l}\text { One surface-exposed epitope was } \\
\text { conserved }\end{array}$ & $\begin{array}{l}\text { Did not presented effective } \\
\text { antigenicity }\end{array}$ & $\begin{array}{l}\text { After in vitro and vivo trials did not demonstrated effective } \\
\text { antigenicity [36] }\end{array}$ \\
\hline Outer Membrane Protein - P6 & $\begin{array}{l}1 \text { surface epitope common to all strains, } \\
\text { conserved among encapsulated and } \\
\text { nonencapsulated } H \text {. influenzae strains }\end{array}$ & $\begin{array}{l}\text { Cannot be a transmembrane } \\
\text { protein and is not conserved in } \\
\text { all NTHi strains [49]. }\end{array}$ & $\begin{array}{l}\text { Mice and rabbits have been shown to produce bactericidal } \\
\text { antibodies after systemic immunization with P6 and } \\
\text { recombinant P6 [44-48]. }\end{array}$ \\
\hline $\begin{array}{l}\text { lipooligosaccharide (LOS)- } \\
\text { tetanus toxoid (TT) }\end{array}$ & Protective against NTHi strains & Not yet tested in children & Well tolerated in adults [49] \\
\hline NTHi OMV & $\begin{array}{l}\text { Protective against NTHi strains. Various } \\
\text { heterologous antigens in the vesicules }\end{array}$ & Not yet tested in humans & $\begin{array}{l}\text { Tests in mice demonstrate a cross-protective immunization } \\
\text { [50]. }\end{array}$ \\
\hline
\end{tabular}

Table 3: Novel Membrane proteins target in Haemophilus influenza.

\begin{tabular}{|c|c|c|c|}
\hline Target & Advantages & Drawbacks & Preliminary data \\
\hline Neisseria Adhesin A- NadA & $\begin{array}{l}\text { Predicted molecular structure strikingly } \\
\text { similar to the known virulence-associated. }\end{array}$ & Based only in one antigen. & $\begin{array}{l}\text { Is capable of generating local and systemic cellular } \\
\text { and humoral immunity when coadministered with } \\
\text { mucosal adjuvants }[26,51,52] \text {. }\end{array}$ \\
\hline Surface Porin - PorA & $\begin{array}{l}\text { N. meningitidis strains express usually } \\
\text { only one kind of porin class. }\end{array}$ & $\begin{array}{l}\text { Vaccines based on this porin are effective } \\
\text { only against clonal epidemics }\end{array}$ & Effective only against clonal epidemics $[25,53]$ \\
\hline $\begin{array}{l}\text { Outer membrane vesicule - OMV } \\
\text { MenBvac }\end{array}$ & $\begin{array}{l}\text { vaccine consists of several recently } \\
\text { discovered, relatively conserved surface } \\
\text { antigens, NadA, fHBP, and NHBA, and a } \\
\text { PorA }\end{array}$ & $\begin{array}{l}\text { Protected only against homologous } \\
\text { meningococal strains. }\end{array}$ & $\begin{array}{l}\text { All four doses of MenBvac are safe, no serious } \\
\text { adverse events occurred }[57,58] \text {. }\end{array}$ \\
\hline $\begin{array}{l}\text { rMenB-OMV -recombinant MenB } \\
\text { with OMV }\end{array}$ & $\begin{array}{l}\text { vaccine consists of several recently } \\
\text { discovered, relatively conserved surface } \\
\text { antigens, NadA, fHBP, and NHBA, and a } \\
\text { PorA }\end{array}$ & $\begin{array}{l}\text { Protected only against homologous } \\
\text { meningococal strains. }\end{array}$ & $\begin{array}{l}\text { Clinical trials revealed that vaccinated individuals } \\
\text { produce bactericidal antibodies, which protect } \\
\text { against infection with homologous meningococcal } \\
\text { strains }[54,55] \text {. }\end{array}$ \\
\hline Intranasal Neisseria OMVB & $\begin{array}{l}\text { Intranasal vaccination with } \mathrm{OMV} \text {, } \\
\text { presenting complex antigens mixture. }\end{array}$ & Still in trials. & $\begin{array}{l}\text { Immunogenicity and safety of a group B vaccine } \\
\text { proved. [59]. }\end{array}$ \\
\hline
\end{tabular}

Table 4: Novel membrane proteins target in Neisseria meningitides.

bactericidal antibodies after systemic immunization with P6 and recombinant P6 [46]. P6 has been a vaccine candidate for nontypable Haemophilus influenzae (NTHi) based on its location on the outer membrane and immunogenicity. Because P6 is attached to the inner peptidoglycan layer of NTHi, and is putatively surface exposed, it should be a transmembrane protein. The study of Michel et al. examined the P6 structure using computational modeling, site-directed mutagenesis, and nuclear magnetic resonance spectroscopy and it was found that P6 cannot be a transmembrane protein, and therefore may not be surface exposed. A conclusion that there may be another protein on the surface of NTHi that has epitopes similar if not identical to P6 [47]. And in a study by Chang et al. [48] proved that P6 is not conserved in all NTHi strains. In table 3 we can see a comparison between these proteins and see which one would be more effective.

\section{The Nouvel Vaccine Targets in Neisseria meningitidis}

According to Magagnoli et al. [49] proteins from N. meningitidis were found to be capable of inducing bactericidal antibodies in mice, and were recognized by sera of meningitis patients. Among these proteins NadA (Neisseria Adhesin A) had a predicted molecular structure strikingly similar to the known virulence-associated adhesins YadA and UspA2. This led to the discovery of a number of relatively well conserved and cross-reactive surface proteins, of which factor $\mathrm{H}$-binding protein (fHBP), neisserial adhesion $\mathrm{A}(\mathrm{NadA})$, and neisserial heparin-binding antigen in particular, warranted further investigation as potential components of a broadly cross- protective MenB vaccine [50].
In a study performed by Bowe et al. intranasal immunization of mice with 0,3 and 6 weeks old, with $\mathrm{NadA}(10 \mu \mathrm{g})$, a conserved, putative adhesin found in serogroup B strains of N. meningitidis, is capable of generating local and systemic cellular and humoral immunity when coadministered with mucosal adjuvants in an intranasal via. Moreover, the antibodies induced are bactericidal, a correlate of protection against serogroup B meningococci [26]. One of the most promising among the alternatives being investigated while waiting for a definitive solution is vaccines based on outermembrane proteins (OMPs), especially those that use meningococcal class 1 OMP or porin A (PorA) [51]. The porin, proteins from patoghenic neisseria strains, are important for the serotyping of the antigen, and also for the vaccine development. The majority of the Neisseria specimen express only one kind of porin class, know as Por. These porins are targets for studies of serotyping and the development of vaccines [21].

Vaccines based on the major immunodominant surface porin, PorA, are effective against clonal epidemics but, thus far, have a limited scope of coverage against the wider MenB population at large [25]. Immunity against PorA tends to be highly subtype specific (specifically, for variable region 2 [VR2]), however, and so a single PorA vaccine component would achieve limited coverage against the more diverse MenB populations endemic to many countries and regions [50].

When it comes to the rMenB-OMV vaccine consists of several recently discovered, relatively conserved surface antigens, NadA, fHBP, and NHBA, and a PorA-containing OMV component [52]. This vaccine has met with some success. Clinical trials have revealed that vaccinated individuals produce bactericidal antibodies, which protect 
against infection with homologous meningococcal strains, but since $N$. meningitidis species are subject to antigenic variation, they offer no protection against infection with heterologous strains [53].

A novel antigen that induces cross-reactive bactericidal antibodies against a number of Neisseria meningitidis strains, a $28 \mathrm{kDa}$ lipoprotein called LP2086, was first observed within a complex mixture of soluble outer membrane proteins (sOMPs) following a series of fractionation, protein purification, and proteomics steps. Approximately 95 different neisserial isolates tested positive by Western blotting and PCR screening methods for the presence of the protein and the gene encoding LP2086. A gene encoding one variant of LP2086 was identified in our analysis of the Sanger Institute N. meningitidis serogroup A Z2491 early release of genomic sequence in contig form [54]. In table 4 we can visualize the targets and the advantages and drawbacks from them.

\section{Membrane Antigens Distinct from Polysaccharides}

An alternative approach to vaccine development is based on surface exposed proteins contained in outer membrane vesicles. These vaccines have been shown both to elicit serum bactericidal antibody responses and to protect against meningococcal disease in clinical trials [39].

The prediction of efficacy of Neisseria meningitidis serogroup B (MenB) vaccines is currently hindered due to the lack of an appropriate correlate of protection. For outer membrane vesicle (OMV) vaccines, immunogenicity has primarily been determined by the serum bactericidal antibody (SBA) assay and OMV enzymelinked immunosorbent assay (ELISA) [55]. In another study by Feiring et al. [56] a MenBvac that is an outer membrane vesicle vaccine against systemic meningococcal disease caused by serogroup B Neisseria meningitids showed that all four doses of MenBvac are safe, the MenBvac and the placebo had reactogenicity profiles of mild to moderate local and systemic reactions. Pain was the most common side effect, no serious adverse events occurred. This study confirmed the good immunogenicity of the primary course of MenBvac and demonstrated prolonged persistence and increased cross-reactivity of functional antibodies elicited by a booster dose [56].

Another type of OMV was tested to evaluate the safety and immunogenicity of an intranasal native outer membrane vesicle (NOMV) vaccine prepared from a capsule negative strain of group B of Neisseria meningitidis. In this study all volunteers received the same dose of vaccine, intranasal and serum vaccine-specific antibodies were measured as well as serum bactericidal activity. The vaccine was well tolerated without evidence of inflammation on nasal cytology. The group receiving the extra vaccine dose showed the maximum increase in bactericidal activity. We have demonstrated the immunogenicity and safety of a group B lipopolysaccharide-containing, intranasal, NOMV vaccine [57].

OMV s from $H$. influenzae NTHi were also made and tested in a study by Roier et al, the mice were vaccinated with $25 \mu \mathrm{g}$ of OMV from NTHi intranasally or $2 \mu \mathrm{g}$ of OMV from NTHi intraperitoneally. Antibody titers in serum to OMVs were monitored at four time points before (day 0 ), during (day 14 and 28), and after (day 39) the immunization period by using an indirect ELISA. This study has demonstrated an induction of cross-protective immunization [58].

Based upon sero-epidemiological data in humans and immunochemical data in laboratory animals, a lipooligosaccharide (LOS)-tetanus toxoid (TT) conjugate was prepared and evaluated for its safety and immunogenicity for phase I for NTHi Haemophilus influenzae The LOS-TT conjugate is well tolerant in adults and a Phase II evaluation of the conjugate in children is planned [59].

\section{Conclusions}

Therefore there is still no ideal vaccine for $N$. meningitidis $\mathrm{B}$ or NTHi. These microorganisms suffer modifications from time to time so that they manage to evolve and escape the hosts' defense mechanism. Hence continuous research in the area is needed. H. influenzae and $N$. meningitidis are commensal bacteria; however once they manage to mutate or exchange DNA material, such as resistance plasmids - in case of $H$. influenzae - they can become pathogens and cause diseases. Vaccines targets are always going to be needed in order to accompany their evolution. Based in the research we can conclude that the most prominent vaccine candidates for $H$. influenzae would be the porin proteins $\mathrm{P} 2$ and the OMV strategy. Because the OMV carries more antigens and enables for the organism to be more exposed to them rather than just a single antigen (as verified in the figure 1). As for the P2 porin, it is probably one of the most conserved outer membrane protein in between strains of typable and non typable $H$. influenzae. The N. meningitids OMV based vaccines will be probably be soon in the market for use after trials, since it would be the only vaccine against emerging serogroup B. In both cases a new via of administration for these vaccines is being studied and well tolerated: intranasal. Since both bacteria are upper respiratory tract commensal, the immunity response is enhance in this via at this moment. However, the antibodies production by intranasal administration via is not verified by long term (immunologic memory by years for example), which rise in doubt the real efficiency of this procedure. To sum up additional targets are available and being explored in order to bring new vaccines.

\section{Acknowledgments}

Thanks for FAPESP (2011/14079-2 and 2012/15046-3) and CAPES (fellowship granst to Julia N. Varela) for the financial support for the Biotechnology Laboratory.

\section{References}

1. Wolf J, Daley AJ (2007) Microbiological aspects of bacterial lower respiratory tract illness in children: typical pathogens. Paediatr Respir Rev 8: 204-210.

2. Lancellotti M, Pace F, Stehling EG, Villares MC, Brocchi M, et al. (2008) Ribotyping, biotyping and capsular typing of Haemophilus influenzae strains isolated from patients in Campinas, southeast Brazil. Braz J Infect Dis 12: 430 437

3. Peltola H (2000) Worldwide Haemophilus influenzae type b disease at the beginning of the 21st century: global analysis of the disease burden 25 years after the use of the polysaccharide vaccine and a decade after the advent of conjugates. Clin Microbiol Rev 13: 302-317.

4. Turk DC (1984) The pathogenicity of Haemophilus influenzae. J Med Microbio 18: $1-16$

5. Booy R, Heath PT, Slack MP, Begg N, Moxon ER (1997) Vaccine failures afte primary immunisation with Haemophilus influenzae type-b conjugate vaccine without booster. Lancet 349: 1197-1202.

6. Rahman M, Hossain S, Baqui $A H$, Shoma S, Rashid H, et al. (2008) Haemophilus influenzae type-b and non-b-type invasive diseases in urban children (<5years) of Bangladesh: implications for therapy and vaccination. $J$ Infect 56: 191-196.

7. Wang SR, Tseng MH, Lin WJ, Teng CS, Wang CC (2005) Fatal non-typeable Haemophilus influenzae sepsis complicated with acute respiratory distress syndrome: case report and literature review. Scand J Infect Dis 37: 921-925.

8. van Wessel K, Rodenburg GD, Veenhoven RH, Spanjaard L, van der Ende A, et al. (2011) Nontypeable Haemophilus influenzae invasive disease in The Netherlands: a retrospective surveillance study 2001-2008. Clin Infect Dis 53 : e1-e7.

9. Bajanca P, Canica M (2004) Emergence of nonencapsulated and encapsulated 
Citation: Varela JN, Izidoro Jr MS, de Hollanda LM, Lancellotti M (2012) Membrane Protein as Novel Targets for Vaccine Production in Haemophilus influenzae and Neisseria meningitidis. J Vaccines Vaccin 3:152. doi:10.4172/2157-7560.1000152

non-b-type invasive Haemophilus influenzae isolates in Portugal (1989-2001). J Clin Microbiol 42: 807-810.

10. Greenberg-Kushnir N, Haskin O, Yarden-Bilavsky H, Amir J, Bilavsky E (2012) Haemophilus influenzae Type b Meningitis in the Short Period after Vaccination: A Reminder of the Phenomenon of Apparent Vaccine Failure. Case Rep Infect Dis. 2012: 950107

11. Galil K, Singleton R, Levine OS, Fitzgerald MA, Bulkow L, et al. (1999) Reemergence of invasive Haemophilus influenzae type $b$ disease in a wellvaccinated population in remote Alaska. J Infect Dis 179: 101-106.

12. Chandra S, Singh D, Singh TR (2010) Prediction and characterization of T-cell epitopes for epitope vaccine design from outer membrane protein of Neisseria meningitidis serogroup $B$. Bioinformation 5: 155-161.

13. Snape MD, Medini D, Halperin SA, DeTora L, Drori J, et al. (2012) The challenge of post-implementation surveillance for novel meningococcal vaccines. Vaccine 30: B67-B72.

14. Campbell JD, Edelman R, King JC Jr, Papa T, Ryall R, et al. (2002) Safety, reactogenicity, and immunogenicity of a tetravalent meningococcal polysaccharide-diphtheria toxoid conjugate vaccine given to healthy adults. $J$ Infect Dis 186: 1848-1851.

15. Rosenstein NE, Perkins BA, Stephens DS, Popovic T, Hughes JM (2001) Meningococcal disease. N Engl J Med 344: 1378-1388.

16. Gasparini R, Panatto D (2011) Meningococcal glycoconjugate vaccines. Hum Vaccin 7: 170-182

17. Recommendations of the Advisory Committee on Immunization Practices (ACIP) (2000) Prevention and control of meningococcal disease. MMWR Recomm Rep 49: 1-10.

18. Keyserling H, Papa T, Koranyi K, Ryall R, Bassily E, et al. (2005) Safety, immunogenicity, and immune memory of a novel meningococcal (groups A, C, $\mathrm{Y}$, and $\mathrm{W}-135)$ polysaccharide diphtheria toxoid conjugate vaccine (MCV-4) in healthy adolescents. Arch Pediatr Adolesc Med 159: 907-913.

19. Bae S, Lee J, Lee J, Kim E, Lee S, et al. (2010) Antimicrobial resistance in Haemophilus influenzae respiratory tract isolates in Korea: results of a nationwide acute respiratory infections surveillance. Antimicrob Agents Chemother 54: 65-71.

20. Koyama J, Ahmed K, Zhao J, Saito M, Onizuka S, et al. (2007) Strain-specific pulmonary defense achieved after repeated airway immunizations with nontypeable haemophilus influenzae in a mouse model. Tohoku J Exp Med 211: $63-74$

21. Oliveira AMF, Santos JEF, Oliveira LL, Souza LBS, Santana WJ, et al. (2004) Fatores de virulência de Neisseria spp. Arq Ciênc Saúde Unipa 8: 39-44.

22. Neary JM, Yi K, Karalus RJ, Murphy TF (2001) Antibodies to loop 6 of the P2 porin protein of nontypeable Haemophilus influenzae are bactericidal against multiple strains. Infect Immun 69: 773-778.

23. Sáez-Nieto JA, Lujan R, Berrón S, Campos J, Viñas M, et al. (1992) Epidemiology and molecular basis of penicillin-resistant Neisseria meningitidis in Spain: a 5-year history (1985-1989). Clin Infect Dis 14: 394-402.

24. World Health Organization (2000) Introduction of Haemophilus influenzae type b vaccine into immunization programmes. Management guidelines, including information for health workers and parents. Department of Vaccines and Biologicals, World Health Organization, Geneva.

25. Lucidarme J, Comanducci M, Findlow J, Gray SJ, Kaczmarski EB, et al. (2010) Characterization of $\mathrm{fHbp}$, nhba (gna2132), nadA, porA, and sequence type in group $B$ meningococcal case isolates collected in England and Wales during January 2008 and potential coverage of an investigational group B meningococcal vaccine. Clin Vaccine Immunol 17: 919-929.

26. Bowe F, Lavelle EC, McNeela EA, Hale C, Clare S, et al. (2004) Mucosal vaccination against serogroup $B$ meningococci: induction of bactericidal antibodies and cellular immunity following intranasal immunization with NadA of Neisseria meningitidis and mutants of Escherichia coli heat-labile enterotoxin. Infect Immun 72: 4052-4060.

27. PAPR (2010) New drug information: Menveo. JAAPA 23: 14.

28. MENVEO ${ }^{\circledR}$ [Meningococcal (Groups A, C, Y and W-135) Oligosaccharide Diphtheria CRM197 Conjugate Vaccine] Solution for intramuscular injection.

29. Menactra ${ }^{\circledR}$ (Meningococcal (Groups A, C, Y and W-135) Polysaccharide Diphtheria Toxoid Conjugate Vaccine, FDA, Editor. 2011.
30. Meningococcal Polysaccharide Vaccine, Groups A, C, Y and W-135 Combined Menomune ${ }^{\circledR}-\mathrm{A} / \mathrm{C} / \mathrm{Y} / \mathrm{W}-135$.

31. Cochi SL, Broome CV, Hightower AW (1985) Immunization of US children with Hemophilus influenzae type b polysaccharide vaccine. A cost-effectiveness model of strategy assessment. JAMA 253: 521-529.

32. Baggett HC, Hennessy TW, Bulkow L, Romero-Steiner S, Hurlburt D, et al (2006) Immunologic response to Haemophilus influenzae type b (Hib) conjugate vaccine and risk factors for carriage among Hib carriers and noncarriers in Southwestern Alaska. Clin Vaccine Immunol 13: 620-626.

33. Confidential/Proprietary Information (2009) Haemophilus b Conjugate Vaccine (Tetanus Toxoid Conjugate) ActHIB ${ }^{\circledR}$.

34. Liquid PedvaxHIB ${ }^{\circledR}[$ Haemophilus b Conjugate Vaccine (Meningococcal Protein Conjugate)].

35. Barenkamp SJ, Munson RS Jr, Granoff DM (1981) Subtyping isolates of Haemophilus influenzae type $b$ by outer-membrane protein profiles. J Infect Dis 143: 668-676.

36. Foxwell AR, Kyd JM, Cripps AW (1998) Nontypeable Haemophilus influenzae: pathogenesis and prevention. Microbiol Mol Biol Rev 62: 294-308.

37. Murphy TF, Bartos LC (1988) Purification and analysis with monoclona antibodies of P2, the major outer membrane protein of nontypable Haemophilus influenzae. Infect Immun 56: 1084-1089.

38. Murphy TF, Bartos LC (1988) Human bactericidal antibody response to oute membrane protein P2 of nontypeable Haemophilus influenzae. Infect Immun 56: 2673-2679

39. Comanducci M, Bambini S, Brunelli B, Adu-Bobie J, Aricò B, et al. (2002) NadA a novel vaccine candidate of Neisseria meningitidis. J Exp Med 195: 14451454.

40. Jacobsson S, Molling P, Olcen P (2009) Seroprevalence of antibodies against $\mathrm{fHbp}$ and NadA, two potential vaccine antigens for Neisseria meningitidis. Vaccine 27: 5755-5759.

41. Loeb MR, Smith DH (1980) Outer membrane protein composition in disease isolates of Haemophilus influenzae: pathogenic and epidemiological implications. Infect Immun 30: 709-717.

42. Chong P, Yang YP, Persaud D, Haer M, Tripet B, et al. (1995) Immunogenicity of synthetic peptides of Haemophilus influenzae type b outer membrane protein P1. Infect Immun 63: 3751-3758.

43. Sikkema DJ, Murphy TF (1992) Molecular analysis of the P2 porin protein of nontypeable Haemophilus influenzae. Infect Immun 60: 5204-5211.

44. Murphy TF, Bartos LC, Campagnari AA, Nelson MB, Apicella MA (1986) Antigenic characterization of the P6 protein of nontypeable Haemophilus influenzae. Infect Immunity 54: 774-779.

45. Munson RS Jr, Granoff DM (1985) Purification and partial characterization of outer membrane proteins P5 and P6 from Haemophilus influenzae type b. Infect Immun 49: 544-549.

46. Deich RA, Anilionis A, Fulginiti J, Metcalf BJ, Quataert S, et al. (1990) Antigenic conservation of the 15,000-dalton outer membrane lipoprotein PCP of Haemophilus influenzae and biologic activity of anti-PCP antisera. Infect Immun 58: 3388-3393.

47. Michel LV, Kalmeta B, McCreary M, Snyder J, Craig P, et al. (2011) Vaccine candidate P6 of nontypable Haemophilus influenzae is not a transmembrane protein based on protein structural analysis. Vaccine 29: 1624-1627.

48. Chang A, Kaur R, Michel LV, Casey JR, Pichichero M (2011) Haemophilus influenzae vaccine candidate outer membrane protein P6 is not conserved in all strains. Hum Vaccin 7: 102-105.

49. Magagnoli C, Bardotti A, De Conciliis G, Galasso R, Tomei M, et al. (2009) Structural organization of NadADelta(351-405), a recombinant MenB vaccine component, by its physico-chemical characterization at drug substance level. Vaccine 27: 2156-2170.

50. Lucidarme J, Newbold LS, Findlow J, Gilchrist S, Gray SJ, et al. (2011) Molecular targets in meningococci: efficient routine characterization and optimal outbreak investigation in conjunction with routine surveillance of the meningococcal group B vaccine candidate, fHBP. Clin Vaccine Immunol 18 194-202.

51. Frasch CE, van Alphen L, Holst J, Poolman JT, Rosenqvist E (2001) Outer 
Citation: Varela JN, Izidoro Jr MS, de Hollanda LM, Lancellotti M (2012) Membrane Protein as Novel Targets for Vaccine Production in Haemophilus influenzae and Neisseria meningitidis. J Vaccines Vaccin 3:152. doi:10.4172/2157-7560.1000152

membrane protein vesicle vaccines for meningococcal disease. Methods $\mathrm{Mol}$ Med 66: 81-107.

52. Giuliani MM, Adu-Bobie J, Comanducci M, Aricò B, Savino S, et al. (2006) A universal vaccine for serogroup B meningococcus. Proc Natl Acad Sci U S A 103: $10834-10839$

53. Poolman JT (1995) Development of a meningococcal vaccine. Infect Agents Dis 4: $13-28$

54. Fletcher LD, Bernfield L, Barniak V, Farley JE, Howell A, et al. (2004) Vaccine potential of the Neisseria meningitidis 2086 lipoprotein. Infect Immun 72: 20882100 .

55. Findlow J, Lowe A, Deane S, Balmer P, van den Dobbelsteen G, et al. (2005) Effect of sequence variation in meningococcal PorA outer membrane protein on the effectiveness of a hexavalent PorA outer membrane vesicle vaccine in toddlers and school children. Vaccine 23: 2623-2627.
56. Feiring B, Fuglesang J, Oster P, Naess LM, Helland OS, et al. (2006) Persisting immune responses indicating long-term protection after booster dose with meningococcal group B outer membrane vesicle vaccine. Clin Vaccine Immunol 13: 790-796.

57. Katial RK, Brandt BL, Moran EE, Marks S, Agnello V, et al. (2002) Immunogenicity and safety testing of a group $B$ intranasal meningococcal native outer membrane vesicle vaccine. Infect Immun 70: 702-707.

58. Roier S, Leitner DR, Iwashkiw J, Schild-Prüfert K, Feldman MF, et al. (2012) Intranasal Immunization with Nontypeable Haemophilus influenzae Outer Membrane Vesicles Induces Cross-Protective Immunity in Mice. PLoS One 7: e42664.

59. Gu XX, Rudy SF, Chu C, McCullagh L, Kim HN, et al. (2003) Phase I study of a lipooligosaccharide-based conjugate vaccine against nontypeable Haemophilus influenza. Vaccine 21: 2107-2114. 